\title{
ORIGINAL
}

\section{Establishment of EGF receptor-bearing cell lines by fusion between hamster embryonic palatal cells and mouse $\mathrm{Ltk}^{-}$cells}

\author{
Toshio Kukita, Takeshi Sakai ${ }^{*}$, and Kojiro Kurisu \\ (Chief: Prof. K. Kurisu) \\ Second Department of Oral Anatomy, and ${ }^{*}$ Department of Orthodontics, \\ Faculty of Dentistry, Kyushu University, Maidashi, \\ Higashi-ku, Fukuoka 812, Japan
}

〔Accepted for publication: June 2, 1987]

Key words : EGF receptor/hybrid cells / hamster/mouse/palate

\begin{abstract}
Hamster embryonic palatal cells, which have functional EGF receptors but a limited life-span, were fused with mouse Ltk-cells, which bear no surface EGF receptors but have an infinite life-span. After HAT selection and cloning, the following three types of cell lines were obtained: i) clones bearing EGF receptors and having a proliferative response to EGF, ii) clones having EGF receptors, but unresponsive to EGF, and iii) clones bearing no EGF receptors and having no proliferative response to EGF. These cells provide appropriate materials for investigations into the role of EGF-receptors in the induction of cell proliferation by EGF. Cells of the first type will be a good source of immunogen for the production of antibodies against embryonic EGF receptors, which will be useful for the examination of the role of EGF in palatogenesis.
\end{abstract}

\section{Introduction}

Epidermal growth factor (EGF) is thought to have some important roles in palate formation in mammalian embryos ${ }^{1-5)}$. During palate formation in mouse embryos, the amount of EGF receptors in the palate increases from day 12 to 14 of gestation ${ }^{6}$, suggesting the importance of this factor in normal palatogenesis.

It is of interest to study when and where EGF receptors appear in tissues of developing palates; however, there are very few histological studies of their distribution. Although $\mathrm{Ne} \phi$ et al. $(1980)^{7}$ reported the distribution of EGF receptors in organ cultures of dissected palates by using ${ }^{125}$ I-labelled EGF, the detailed distribution was not described. Immunohistochemical examination would provide the answer for determining the preci- se distribution of EGF receptors in the palate. Therefore, it is necessary to obtain specific antibodies against embryonic EGF receptors. Usually, A431 cells have been the source of EGF receptors for obtaining antibodies against EGF receptors ${ }^{7-11}$, as these human epidermoid carcinoma cells bear an extremely high number of EGF receptors (ca. $2 \times 10^{6}$ per cell), much higher than other cells. It may be possible therefore to study the distribution of EGF receptors in palates of rodent embryos by using polyclonal or monoclonal antibodies against EGF receptors prepared from A431 cells, but only if the antibodies are able to cross-react with EGF receptors of rodent tissues. However, we think that the best way is to prepare antibodies against the embryonic EGF receptors themselves, using receptors in palatal processes of rodents, because EGF might fu- 
nction differently throughout development probably by modification of EGF receptor molecules, as suggested by Adamson and Meek $(1984)^{12}$.

As a source of embryonic EGF receptors, we first planned to use diploid palatal cells derived from hamster embryos; however, only a limited amount of EGF receptors can be isolated from these cells because of their limited life-span. Therefore, we decided to establish hybrid cell lines bearing embryonic EGF receptors, by hydridizing diploid hamster palatal cells, which bear embryonic EGF receptors, with mouse $\mathrm{Ltk}^{-}$cells, which are "immortal" and have no surface EGF recep. tors $^{13)}$.

\section{Materials and Methods}

\section{Cell culture}

Palatal cells were prepared from hamster embryos of 12 days of gestation. Dissected palatal processes were treated with $0.25 \%$ trypsin for about 30 minutes at $37^{\circ} \mathrm{C}$ and then pipetted vigorously, followed by filtration of these dissociated cells through a platinum mesh. After centrifugation to remove trypsin, the cells were cultured in Dulbecco's modified Eagle (DME) medium containing $10 \%$ fetal calf serum (FCS). Passages of these cells were performed with $0.05 \%$ trypsin containing $0.02 \%$ EDTA. Ltk- cells were cultured using the same medium as described above except that $0.25 \%$ trypsin was used for passages.

Cell fusion and HAT selection.

The cell fusion technique was performed by using polyethylene glycol, mainly as described by Pontecorvo $(1975)^{14}$. Confluent monolayer cultures of both cells in $60 \mathrm{~mm}$ dishes were trypsinized and collected separately, followed by washing with serum-free DME medium. Then both cells in equal numbers were resuspended in serum-free DME medium, mixed, and centrifuged. After complete removal of the medium, $1.0 \mathrm{~m} l$ of $42.5 \%$ (w/ v) polyethylene glycol 1000 was added dropwise with occasional shaking of the tube. The tube was then kept motionless for 5 to 6 minutes, after which the fusion reaction was stopped by the addition of serum-free DME medium. The cells were then centri- fuged, seeded into a $100 \mathrm{~mm}$ dish, and cultured overnight, followed by the selection of hybrid cells. The medium was changed to DME containing $10 \% \mathrm{FCS}, 0.1 \mathrm{mM}$ hypoxanthine, $0.4 \mu \mathrm{M}$ aminopterin, and $0.016 \mathrm{mM}$ thymidine (HAT medium) on the day after the fusion event. After two weeks, with feeding every three days, the medium was changed to the normal medium (DME, $10 \%$ FCS) and the cultures were continued. After several passages, HAT selection was repeated at least four more times. All passages are performed with $0.25 \%$ trypsin.

\section{Cloning}

HAT-selected cells were trypsinized followed by successive dilution of the cell suspension. A small number of these cells (five to twenty cells) were seeded into each of several $10 \mathrm{~mm}$ dishes and cultured in normal medium for about 2 weeks. Clones were observed by the naked eye and colony positions were marked with a felt pen on the bottom of each dish. Very small pieces of sterile filter paper $(1 \mathrm{~mm} \times 1 \mathrm{~mm})$ that had been immersed in $0.25 \%$ trypsin were placed on each colony, followed by incubation for 10 minutes at $37^{\circ} \mathrm{C}$. These filter papers, to which the trypsinized cells adhered, were picked up and placed into $35 \mathrm{~mm}$ dishes containing normal medium. Then the clones were cultured.

\section{${ }^{125} I-E G F$ binding studies}

Studies on the binding of EGF to various cell types were performed as described before ${ }^{15)}$.

\section{Materials}

Mouse $\mathrm{Ltk}^{-}$cells were a kind gift from Dr. S. Shiota of the Department of Oral Microbiology, Kyushu University. Mouse L cells were given by Mrs. A. Kukita of Saga Medical School. Polyethylene glycol 1000 was purchased from Wako Co. Ltd. (Osaka, Japan). Hypoxanthine, aminopterin, and thymidine were obtained from Sigma Chemical Co. (St Louis, Missouri).

\section{Results}

After the successive selection with HAT medium, a cell population able to proliferate for a long period of time was obtained. These cells could grow to confluence even if 
they were seeded sparsely at a cell number of less than $10^{4}$ cells per $35 \mathrm{~mm}$ dish. Under our culture conditions, normal diploid fibroblast cells do not proliferate if seeded so sparsely. Therefore, we thought that the cells we had obtained by HAT selection might have the ability to form colonies even when very few were seeded into dishes. After seeding 5 to 20 cells per $100 \mathrm{~mm}$ dish, cultures were continued for about two weeks without changing the medium. Colonies first became visible after about one week of culture. Cell morphology was not the same among colonies, that is, epithelial cell-like, fibroblast cell-like, and neuronal cell-like colo nies were observed. Each colony was picked up as described in MATERIALS AND METHODS and recloned once more. A total of fifty-one clones was thus obtained. As these cells obtained by HAT selection have the ability to form colonies under culture conditions in which normal diploid fibroblast never form such colonies, it appears they have at least some properties of transformed cells, probably derived from the $\mathrm{Ltk}^{-}$cells.

Cell growth in HAT medium and normal medium.

We have exmined the growth properties of the two parental cells and of the obtained clones. Fig. 1 shows the growth curves of the parent cells. Palatal cells derived from hamster embryos can proliferate in HAT medium as in normal medium (Fig. 1a) because normal diploid cells bear thymidne kinase and therefore can utilize the salvage pathway of DNA synthesis even when the de novo pathway is blocked by an inhibitor of dihydrofolate reductase, aminopterin, which is included in the HAT medium. The other parent cell, the $\mathrm{Ltk}^{-}$, can not proliferate at all in HAT medium (Fig. 1b) because of its deficiency in thymidine kinase.
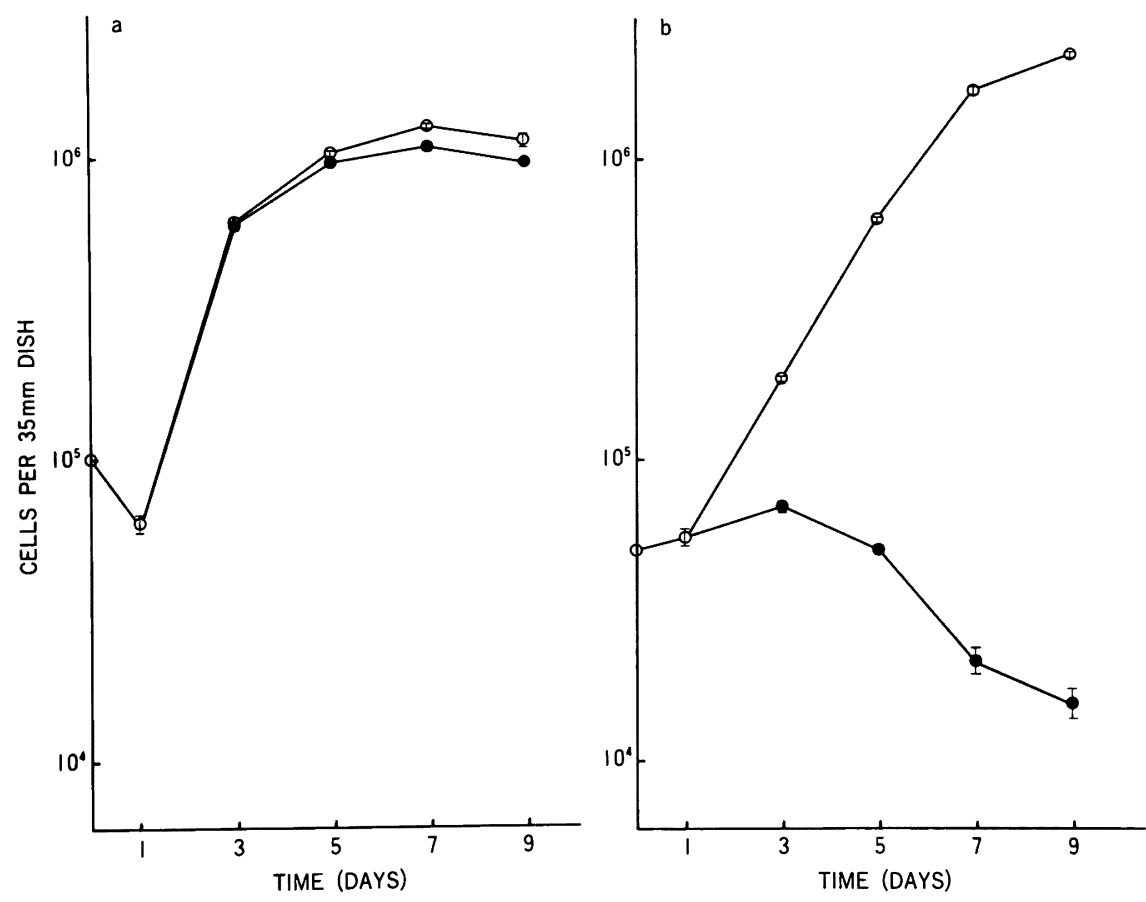

Fig. 1 Cell growth curves of hamster embryonic palatal cells (a) and Ltk ${ }^{-}$cells (b). Cells were seeded at a cell number of $10^{5}$ (a) or $5 \times 10^{4}$ (b) per $35 \mathrm{~mm}$ dish, followed by culture for 1 to 9 days in the normal (O) or HAT ( $)$ medium. The medium was changed on day 1,3 , and 5 of culture. Cells of each dish were trypsinized and counted by haemocytometer. Each point represents the mean value from triplicate dishes (mean value $\pm \mathrm{SE}$ ). 

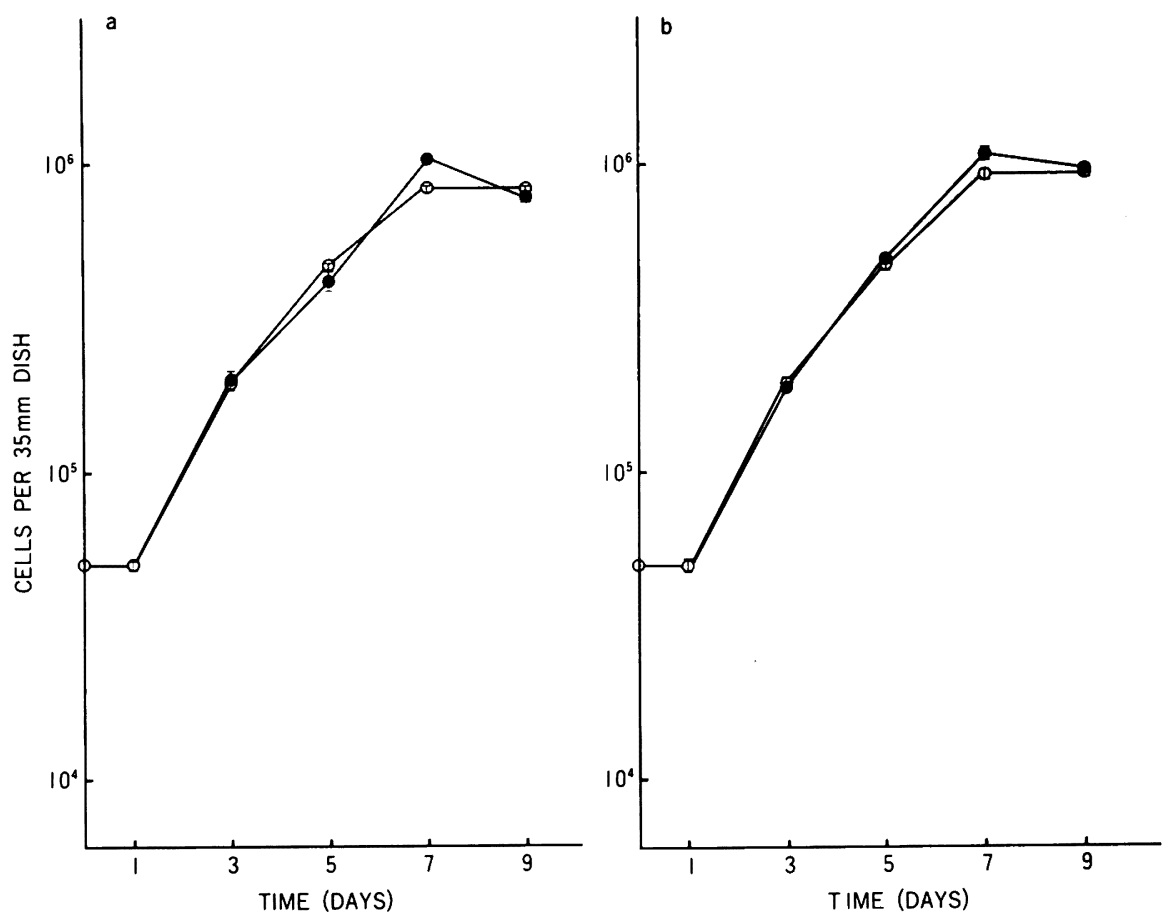

Fig. 2 Cell growth of typical hybrid clones. The experiment was performed as described in the legend to Fig. 1. (a) B604A and (b) B604B clones. Growth curves in normal medium (O) and in HAT medium (๑).

Cell growth of two representative clones, $\mathrm{B} 604 \mathrm{~A}$ and $\mathrm{B} 604 \mathrm{~B}$, of the fifty-one obtained is shown in Fig. 2a, 2b. As is evident, these clones can proliferate in HAT medium as well as in normal medium, indicating that these clones have thymidine kinase.

From the facts that these clones were obtained by cloning twice and that they have thymidine kinase probably derived from palatal cells from hamster embryos, we regard them as hybrids between the two parent cells.

Cell morphology of various clones

As shown in Fig. 3, each clone showed one of a variety of cell morphologies,; eg, epithelial cell-like (Fig. 3c), firbroblastlike (Fig. 3d), neuronal cell-like (Fig. 3e), and other types of cell morphology (Fig. 3f, $3 \mathrm{~g}$ and $3 \mathrm{~h}$ ). There were also some clones that formed characteristic cell aggregates, as shown in Fig. $3 \mathrm{i}$ and $3 \mathrm{j}$.

Mitogenic response to EGF and EGF receptor amounts of hybrid cells

As shown in Table 1 , hamster palatal cells have receptors for EGF and their growth was stimulated by $10 \mathrm{ng} / \mathrm{ml}$ EGF. In contrast, $\mathrm{Ltk}^{-}$cells have no receptors for EGF and their growth was not stimulated by EGF at all. Some hybrid cell clones have receptors for EGF and their growth is clearly stimulated by EGF (clones A524fib, B604A, B604B, C528A, HA527A, HA527B, I531B, NI531D, NI531E). Other clones have receptors for EGF ; however, their growth was not stimulated by EGF (clones A527B, A605F, C528$\mathrm{B}, \mathrm{F} 528 \mathrm{~B}, \mathrm{~F} 528 \mathrm{C}, \mathrm{I} 531 \mathrm{E})$. There were also some clones that have no EGF receptors, nor was their growth stimulated at all by EGF (clones E528A, E531C, RO605A). In order to visualize the relationship between the amounts of EGF receptors and the mitogenic response to EGF in these clones, we have plotted the data of Table 1 in graphic form in Fig. 4. Only clones bearing more than about $10 \mathrm{fmol}$ of ${ }^{125} \mathrm{I}-\mathrm{EGF}$ binding sites per $10^{5}$ cells (about $6 \times 10^{4}$ binding sites per cell) could be stimulated in their growth by EGF. Thus some threshold may exist in 


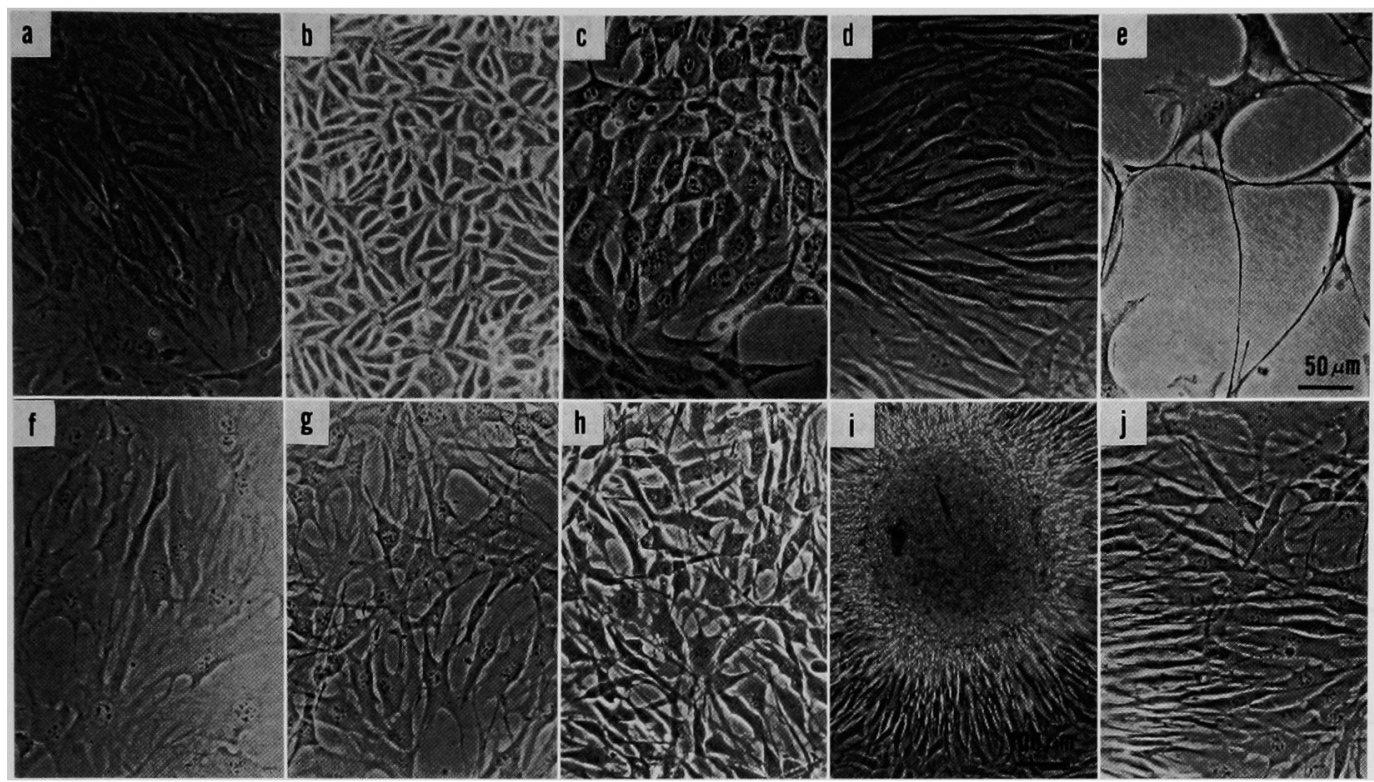

Fig. 3 Phase-contrast micrographs of various clones. (a) Hamster palatal cells, (b) Ltk-cells, (c) A605F, (d) A524fib, (e) I531E, (f) NI531D, (g) B604B, (h) C528B, (i), and (j) E531C. Original magnification was $\times 2000(a-h, j)$ or $\times 100(i)$.

the number of EGF receptor sneeded for the stimulation of cell growth.

\section{Discussion}

We have obtained hybrid cell clones between hamster embryonic palatal cells and mouse $\mathrm{Ltk}^{-}$cells by cell fusion using poly. ethylene glycol 1000 followed by HAT selection and cloning. Since they have the ability to form clones and proliferate in HAT medium, these clones are thought to have inherited some of the properties of both parent cells. Although it might be thought that these clones are $\mathrm{Ltk}^{+}$revertants of $\mathrm{Ltk}^{-}$cells, this is probably not the case since the hybrids bear EGF receptors. It is strongly suggested that these receptors have come from the palatal cell parent, because mouse $\mathrm{L}$ cells $\left(\mathrm{tk}^{+}\right)$, the origin of Ltk-mutant cells, have no detectable surface receptors for EGF according to our ${ }^{125}$ I-EGF binding experiment. Of the hybrid cells we have obtained, those bearing many functional receptors for EGF and having high saturation densities (e.g., B604A, $\mathrm{B} 604 \mathrm{~B}$, HA527A, and HA527B) could be utilized as sources of hamseer embryonic EGF receptors for the preparation of antisera a- gainst the receptors.

Adamson and Meek (1984) ${ }^{12}$ reported that the number of EGF receptors increased during mouse development in all tissues they had, examined, but that the affinity of the receptors declined in carcass and placenta and remain relatively unchanged in brain and liver. Therefore they suggested EGF that EGF might function differently throughout development, probably by modification of EGF receptor molecules, and they proposed that such changes in the nature of EGF receptors during development could occur o nly by alteration of their carbohydrate moiety. Therefore, we think it important to get antibodies specific for embryonic EGF receptors and to study the changes in distribution of embryonic EGF receptors and their biochemical properties for the the purpose of understanding palatogenesis from the stand-point of endocrinology.

According to our growth data on these hybrid cells, only those which have more than about $6 \times 10^{4}$ binding sites per cell expressed positive responses, i.e., cell growth, to EGF, suggesting that some threshold may exist in the amount of EGF receptors 
Table 1 Mitogenic responses of selected clones to EGF and amounts of EGF receptor. Each clone was seeded at a cell number of $5 \times 10$ per $35 \mathrm{~mm}$ dishes followed by culture for 1 day. Then the medium was changed to DME medium containing $10 \%$ FCS with or without $10 \mathrm{ng} / \mathrm{ml}$ EGF and cultured for more 6 days; the cells were then trypsinized and counted by haemorytometer. Medium changes were performed on day 3 and 5 of culture. Experiments were done in triplicate, and each datum of cell growth is the mean value $\pm \mathrm{SE}$. The mean differences in the cell number of cultures treated with EGF and those without EGF were assessed by Student's t-test. (* $\left.: \mathrm{P}<0.05,{ }^{* *}: \mathrm{P}<0.01,^{* * *}: \mathrm{P}<0.001\right)$

Confluent monolayer of each clone were incubated at room temperature for $4 \mathrm{~h}$ in $0.2 \mathrm{ml}$ of the binding medium containing $50 \mathrm{ng} / \mathrm{ml}{ }^{125}$-EGF with (nonspecific binding) or without (total binding) an excess of unlabelled EGF (5 $\mu \mathrm{g} / \mathrm{m} l)$. The amount of non-specific binding was subtracted from that of the total binding to give the specific binding. Each datum indicates the amount of specific binding per 10 cells. The specific radioactivities of 125I-EGF used were 235, 198 and $169 \mathrm{cpm}$ per fmol. Experiments were performed in duplicate.

\begin{tabular}{|c|c|c|c|c|}
\hline cell & \multicolumn{2}{|c|}{$\left(\times 10^{-5}\right.$ cells/dish $)$} & $\frac{+\mathrm{EGF}}{-\mathrm{EGF}}$ & $\begin{array}{c}\text { 125I-EGF } \\
\text { bound } \\
\text { (fmol/ } 10^{5} \text { cells) }\end{array}$ \\
\hline Hamster palatal cells (parent) & $6.58 \pm 0.26$ & $19.56 \pm 0.33$ & $2.97^{* * *}$ & 36.32 \\
\hline Ltk $^{-}$cells (parent) & $23.38 \pm 0.91$ & $23.29 \pm 0.56$ & 1.00 & 0.00 \\
\hline A $524 \mathrm{fib}$ & $5.77 \pm 0.12$ & $6.64 \pm 0.16$ & $1.15^{* *}$ & 10.49 \\
\hline B $604 \mathrm{~A}$ & $7.26 \pm 0.20$ & $10.24 \pm 0.26$ & $1.41^{* * *}$ & 20.89 \\
\hline B 604 B & $9.22 \pm 0.29$ & $12.46 \pm 0.29$ & $1.35^{* * *}$ & 18.92 \\
\hline C $528 \mathrm{~A}$ & $7.93 \pm 0.15$ & $9.32 \pm 0.12$ & $1.18^{* * *}$ & 10.81 \\
\hline HA 527 A & $8.85 \pm 0.23$ & $13.39 \pm 0.26$ & $1.51^{* * *}$ & 16.01 \\
\hline HA $527 \mathrm{~B}$ & $11.56 \pm 0.30$ & $15.72 \pm 0.21$ & $1.36^{* * *}$ & 15.82 \\
\hline I531 B & $2.86 \pm 0.09$ & $3.21 \pm 0.08$ & $1.12^{*}$ & 8.67 \\
\hline NI531 D & $4.64 \pm 0.20$ & $5.61 \pm 0.15$ & $1.21^{* *}$ & 26.86 \\
\hline NI531 E & $3.81 \pm 0.02$ & $5.64 \pm 0.16$ & $1.48^{* * *}$ & 22.00 \\
\hline A $527 \mathrm{~B}$ & $6.03 \pm 0.14$ & $5.70 \pm 0.15$ & 0.95 & 2.52 \\
\hline A $605 \mathrm{~F}$ & $3.98 \pm 0.06$ & $3.87 \pm 0.15$ & 0.97 & 0.81 \\
\hline C $528 \mathrm{~B}$ & $7.78 \pm 0.17$ & $7.66 \pm 0.16$ & 0.98 & 6.27 \\
\hline F $528 \mathrm{~B}$ & $6.94 \pm 0.11$ & $6.88 \pm 0.20$ & 0.99 & 4.68 \\
\hline F $528 \mathrm{C}$ & $6.73 \pm 0.10$ & $6.60 \pm 0.20$ & 0.98 & 1.06 \\
\hline I531 E & $2.84 \pm 0.08$ & $2.98 \pm 0.03$ & 1.01 & 9.64 \\
\hline E $528 \mathrm{~A}$ & $6.34 \pm 0.10$ & $6.19 \pm 0.16$ & 0.98 & 0.00 \\
\hline E $531 \mathrm{C}$ & $7.70 \pm 0.10$ & $7.21 \pm 0.09$ & 0.94 & 0.00 \\
\hline RO $605 \mathrm{~A}$ & $9.48 \pm 0.17$ & $8.61 \pm 0.28$ & 0.91 & 0.00 \\
\hline
\end{tabular}

required for the stimulation of cell growth in these cells. Adamson and Rees (1981) ${ }^{16)}$ stated in their review that no relationship was apparent between EGF receptor number and proliferative responses to EGF when a comparison was made of the data on various types of cells studied by many researchers. The reason why some relationship was not seen between these two parameters is not clear, but, we think that we could see some positive correlation between them because the clones we have obtained had similar properties to each other.

The cell morphology was quite variable between clones; however, the reason for this is not clear. The population of hamster embryonic palatal cells themselves might be heterogenous or certain genes may have been activated by cell fusion, resulting in the appearance of different cell morphologies. Knapp et al. (1985) ${ }^{17)}$ reported that in relation to the expression of genes coding for keratin 


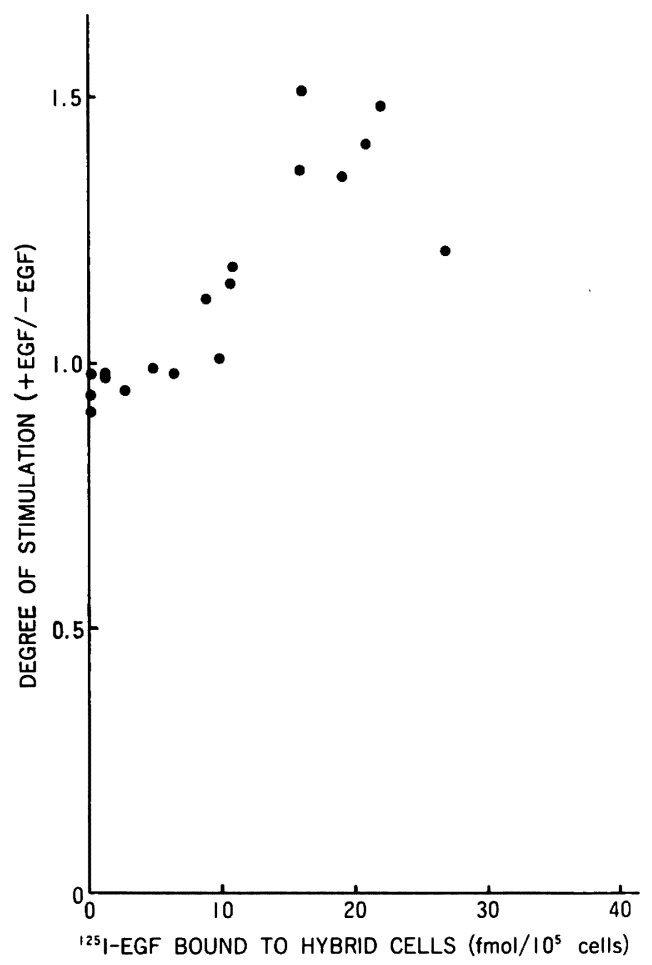

Fig. 4 Relationship between response to EGF and amounts of EGF receptors in various cloned are shown in Table 1 . The amounts of EGF receptors on each clone was plotted against the degree of stimulation of cell growth by EGF $(+\mathrm{EGF} /-\mathrm{EGF})$ on the ordinate. filaments there was a range of morphological differences among hybrid clones between $\mathrm{He}$ $\mathrm{La}$ cells and fibroblasts derived from a human male fetus with Lesch-Nyhan disease and having a deficiency in hypoxanthine phosphoribosyl transferase.

Many of the hybrid cell clones we have obtained in this work should provide appropriate material to reveal the role of EGFreceptors in the induction of cell proliferation by EGF, and they should also provide a sufficient amount of embryonic EGF receptors for use as immunogen and for antibody screening to identify monoclonal antibodies against hamster embryonic EGF receptors.

\section{Acknowledgements}

We thank Dr. S. Shiota for providing us with the $\mathrm{Ltk}^{-}$cells. We thank Drs. Y. Ohsaki, K. Nagata, and M. Yoshikawa for helpful discussions. We also thank Mrs. K. Kuriyama for technical assistance.

抄録: 生理活性のある EGF 受容体をもつが細胞分裂能が有限のハムスター胎仔の口蓋突起細胞と, EGF 受容体はないが無限増殖能を持つマウス Ltk- 株細胞を融合させ, HAT 培地で選択したところ, 次の 3 群のクローンが得られた。(1) EGF 受容体をもち, EGF によって細胞増殖が促進されるクロー ン, (2) EGF 受容体をもつが, EGF に反応しないクローン, (3) EGF 受容体をもたず, EGF に反応 しないクローン。これらのクローンは, EGF による細胞増殖促進における EGF 受容体の役割を解明 する為の研究に有用な材料を提供するものと考えられる。第 1 群のクローンは, 胎仔細胞の EGF 受容 体に対するモノクローナル抗体を作成するさいの抗原の良好な採取源となると考えられる。この抗体を 用いて, 口蓋形成における EGF の役割を追求したい。

\section{References}

1) Pratt, R. M. : Involment of hormones and growth factors in the development of the secondary palate. In Johnson, M. H. (ed) : "Development in Mammals", Vol. 4 pp. 203-231, Amsterdam, Elsevier/North-Holland Health Biomedical Press, 1980.
2) Tyler, M. S. and Pratt, R. M. : Effect of epidermal growth factor on secondary palatal epitheliun in vitro: tissue isolation and recombination studies. J. Embryol. Exp. Morph. $58:$ 93-106, 1980.

3) Yoneda, T. and Pratt, R. M. : Mesenchymal cells from the human embryonic palate are highy responsive to epidermal growth factor. Science 213 : 563-565, 1981. 
4) Grove, R. I. and Pratt, R. M. : Influence of epidermal growth factor and cyclic AMP on growth and differentiation of palatal epithelial cells in culture. Develop. Biol. 106 : 427-437, 1984.

5) Turley, E. A., Holllenberg, M. D. and Pratt, R. M. : Effect of epidermal growth factor/urogastrone on glycosaminoglycan synthesis and accumulation in vitro in the developing mouse palate. Differentiation 28 : 279-285, 1985.

6) Nex $\phi$, E., Hollenberg, M. D., Figueroa, A. and Pratt, R. M. : Detection of epidermal growth factor-urogastrone and its receptor during fetal mouse development. Proc. Natl. Acad. Sci. USA. 77 : 2782-2785, 1980.

7) Schreiber, A. B., Lex, I., Yarden, Y., Eshhar, Z. and Schlessinger, J.: Monoclonal antibodies against receptor for epidermal growth factor induce early and delayed effects of epidermal growth factor. Proc. Natl. Acad. Sci. USA. 78 : 7535-7539, 1981.

8) Waterfield, M. D., Mayes, E. L., Stroobant, P., Bennet, P. L. P., Young, S., Goodfellow, P. N., Banting, G. S. and Ozanne, B. : A monoclonal antibody to the human epidermal growth factor receptor. J. Cell. Biochem. 20 : 149-161, 1982.

9) Kawamoto, T., Sato, J. D., Polikoff, L. A., Sato, G.H. and Mendelsohn, J. : Growth stimulation of A431 cells by epidermal growth factor: Identification of high-affinity receptors for epidermal growth factor by an anti-receptor monoclonal antibody. Proc. Natl. Acad. Sci. USA. 80 : 1337-1341, 1983.

10) Fredman, P., Richert, N. D., Magnani, J. L., Willingham, M. C., Pastan, I. and Ginsburg, V.: A monoclonal antibody that precipitates the glycoprotein receptor for epi- dermal growth factor is directed against the human blood group $\mathrm{H}$ type $\mathrm{I}$ antigen. J. Biol. Chem. 258 : 11206-11210, 1983.

11) Gill, G. N., Kawamoto, T., Cochet, C., Le, A., Sato, J. D., Masui, H., McLeod, C. and Mendelsohn, J.: Monoclonal antiepidermal growth factor receptor antibodies which are inhibitors of epidermal growth factor binding and antagonists of epidermal growth factor stimulated tyrosine protein kinase activity. J. Biol. Chem. 259 : 7755-7760, 1984.

12) Adamson, E. D. and Meek, J. : The ontogeny of epidermal growth factor receptors during mouse development. Develop. Biol. 103 : 62-70, 1984.

13) Kit, S., Dubbs, D. R., Piekarski, L. J. and Hsu, T. C.: Deletion of thymidine kinase activity from $\mathrm{L}$ cells resistant to bromodexyuridine. Eip. Cell Res. 31 : 297-312, 1963.

14) Pontecorvo, G.: Production of mammalian somatic cell hybrids by means of polyethylene glycol treatment. Somatic Cell Genet. 1 : 397-400, 1975.

15) Kukita, T. and Kurisu, K. : Interaction between epidermal growth factor and triamcinolone actonide in mouse palatal mesenchymal cells in vitro. Arch. Oral Biol. 31 : 39-44, 1986.

16) Adamson, E. D. and Rees, A. R. : Epidermal growth factor receptors. Mol. Cell. Biochem. 34 : 129-152, 1981.

17) Knapp, L. W., O'guin, W. M., Sawyer, R. H., Mitchell, D. and Bunn, G. L. : Clonal variations in keratin, intermediate filament expression by human somatic cell hybrids. Exp. Cell Res. 156 : 359-366, 1985. 